\title{
Review on Governance in Hydroelectric Projects and Impacts on Natural Resources
}

\author{
Ediberto Barbosa Lemos ${ }^{1}$, Mariluce Paes-de-Souza ${ }^{1}$, Dercio Bernardes Souza ${ }^{1}$ \& Fabiana Rodrigues Riva ${ }^{1}$ \\ 1 Programa de Pós Graduação Mestrado em Administração da Fundação Universidade Federal de Rondônia \\ (PPGA/UNIR), Brazil
}

Correspondence: Ediberto Barbosa Lemos, Programa de Pós Graduação Mestrado em Administração da Fundação Universidade Federal de Rondônia (PPGA/UNIR), Brazil.

Received: March 22, 2021

Accepted: May 20, 2021

Online Published: November 8, 2021

doi:10.5430/ijba.v12n6p25

URL: https://doi.org/10.5430/ijba.v12n6p25

\begin{abstract}
This article reviewed the literature to highlight how governance in hydroelectric enterprises is configured and the impacts on natural resources resulting from this type of energy production. The methodological procedures were based on the PRISMA recommendation (Main Items for Reporting Systematic Reviews and Meta-analysis) and indexed articles were used from the SCOPUS database. It was evidenced that more than $1 / 3$ of the studies were conducted in Brazil, highlighting the potential of the Amazon region of the country for the construction of hydroelectric dams. Four essential subjects were identified as to be observed by the governance of these enterprises: stakeholder participation, habitat fragmentation, social impacts, and impacts on fish species. These subjects constitute three categories that synthesize governance in hydroelectric projects and the impacts on natural resources: energy policies - which generate benefits for the private sector and contemplate very little the local communities and the environment; water resources and fish - the impacts are related to the type of enterprise to be built, which can compromise the migration and reproduction of fish, in addition to the increasing concentration of nutrients in reservoirs and changes of the water quality; and biodiversity and ecosystem - which are affected by the fragmentation and alteration of natural habitats caused by dam floods.
\end{abstract}

Keywords: governance, hydroelectric enterprises, stakeholders, systematic review

\section{Introduction}

The generation of electrical energy through hydroelectric projects is seen as an essential component to meet energy demand, while offering lower risks to the environment when compared to the generation of thermoelectric or nuclear energy. Although the generation of electricity through hydroelectric plants results in economic and social benefits, there have been an increasing number of reports on concerns about the impacts caused in the social and environmental dimensions (Cooper \& Khagram, 2005).

According to Rai, et. al. (2019), the negative impacts of hydroelectric projects occur directly at the local level and are perceived through environmental disturbances, such as forest degradation, agricultural soils, among others. These events have repercussions on livelihoods and contribute to the reduction of agricultural productivity and water scarcity due to the drying of natural water flows (Chandy, Keenan, Petheram, \& Shepherd, 2012). Other consequences resulting from hydroelectric construction works are linked to demographic transformations, the great social and environmental cost (Tayeng, 2015), and socioeconomic impacts (Diduck, Pratap, Sinclair, \& Deane, 2013).

The process of construction of hydroelectric plants is complex and should consider several factors, including short-term environmental damage, such as: changes in hydrological conditions - variation in flow speed, rate and depth of water at different river ranges; and even interruptions in sediment transfers and impacts on aquatic ecology that can be altered as a result of the project, the conditions of the dam and the river channel (Ghosh, 2011; Guixiang, 2006; Sadler, Verocai, \& Vanclay, 2000).

Amid this complexity of factors and the negative impacts arising from hydroelectric construction works, there are conflicts related to the implementation of hydroelectric projects that are perceived globally as one of the four main reasons for international disputes related to water resources (Yoffe, Wolf, \& Giordano, 2003). Due to the potentiality 
of these conflicts, either due to resource disputes or strong resistance related to environmental aspects, several hydroelectric projects were canceled or suspended indefinitely (Kaygusuz, 2002; Klimpt, Rivero, Puranen, \& Koch, 2002).

Within this multifaceted scenario, governance is an essential instrument to mitigate possible conflicts and impacts on the use of natural resources, and the dispute between stakeholders. Thus, governance can be defined as a process in which new paths are presented and applied to indicate an alternative relationship between the governmental level and social demands and manage the different existing interests (Campos \& Fracalanza, 2010).

In these circumstances, is it questioned how the governance and the impacts on natural resources resulting from hydroelectric projects are configured? The research was developed based on a systematic review of the literature on the theme of governance in hydroelectric projects.

This article consists of sections, in addition to this introduction: theoretical background; methodological procedures; analysis of the data found; discussion around the three lines: implications of governance in energy policies; implications of hydroelectric plants on water and fish resources; and implications of hydroelectric plants on biodiversity and ecosystem. Finally, conclusions, research limitations and suggestions for future studies are presented.

\section{Materials and Methods}

In a scientific investigation, systematic literature reviews improve the quality of the review process and of the obtained results, while guiding the reader on the research path, through a transparent and reproducible procedure with the use of clear criteria of inclusion and exclusion to select the eligible literature (Gough, Oliver, \& Thomas, 2017; Tranfield, Denyer, \& Smart, 2003).

The basis for systematic reviews derives from clear questions, using systematized and explicit methods to identify, select and critically evaluate relevant scientific studies (Galvão, Pansani, \& Harrad, 2015). The basic question for the research was: how are governance and the impacts on natural resources resulting from hydroelectric projects configured? To answer the question, the PRISMA recommendation (Main Items to Report Systematic Reviews and Meta-analyses) was followed, as it is an instrument that includes a checklist with 27 items and a four-step flowchart that enable a better critical evaluation, ensuring scientific rigor and transparency of the steps in systematic review studies (Galvão et al., 2015).

The review was conducted in two stages. The first aimed to research published works on the subject Governance in Hydroelectric Enterprises; the second, to deepen the subject and specifically seek published works on the resolution of conflicts between stakeholders and natural resources arising from hydroelectric projects. The bibliographic research plan included a research at the Scopus database, the choice for this database is justified, because it is considered the largest database of abstracts and citations in the literature with peer review on scientific journals, books, congress processes and publications of the sector (Baas, Schotten, Plume, Côté, \& Karimi, 2020).

To carry out the research, the following keywords and Boolean operators were used: governance*, hydroelectric*, fish, forest, river*, stakeholder*. Only the truncation symbol, the asterisk (*) which is the most flexible of the symbols, was used, because it retrieves any characters or none, thus obtaining derivations of the words.

When searching the descriptors in the base, the item "Topics" was selected, which includes title, abstract and keywords, obtaining a result of 520 samples, with the following filters: scientific papers only; English language. Subsequently, all titles and abstracts of the 520 papers were read, excluding those that were not relevant to the topic and not available for download, resulting in 117 scientific papers. From this sample, and from the subject Governance in Hydroelectric Projects, we again read the titles, abstracts, and keywords, seeking to identify elements related to the resolution of conflicts between stakeholders and natural resources resulting from hydroelectric projects. Which resulted in a final sample of 31 papers?

The 31 scientific papers of the final sample were read in full, and a spreadsheet was prepared in the Microsoft Excel according to PRISMA orientation. After the full reading of the selected material, it was verified that 05 (five) papers had no correlation with the governance approach in hydroelectric projects, being excluded in the eligibility phase.

The selection flow of the papers characterizes the descriptive result and gives the reader an idea of the scope of the search strategy and increases the internal validity of the systematic review. After the eligibility of the papers and the constitution of the textual corpus, the qualitative analysis of the content was performed, adopting for this phase of the research the procedures recommended by Bardin (1977). 
Based on the flow of information from the PRISMA protocol, all the information about the methodological steps was synthesized and presented in Figure 1 below:

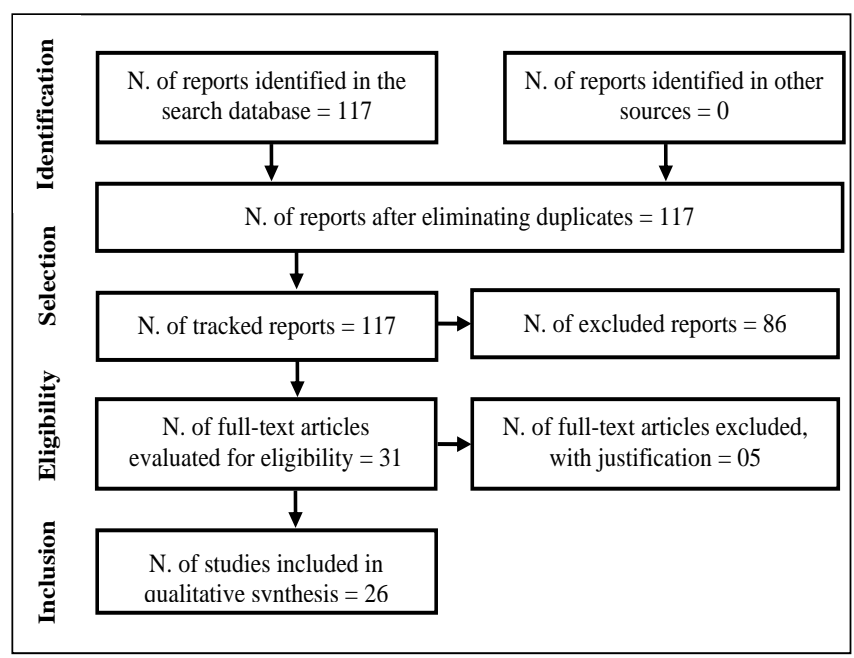

Figure 1. Flow of information from the systematic review adapted from the PRISMA protocol, 2019

\section{Results}

In this systematic review of the literature, 26 papers from 20 journals that present relevant information on governance in hydroelectric enterprises were analyzed. Among these journals, Sustainability Switzerland with 3 publications; and Biological Conservation, Environmental Biology of Fishes, Plos One and Water Alternatives stood out with greater representation, with 2 publications each. The results of the literature analysis of the analyzed articles were grouped into 7 main themes and are illustrated in Figure 2:

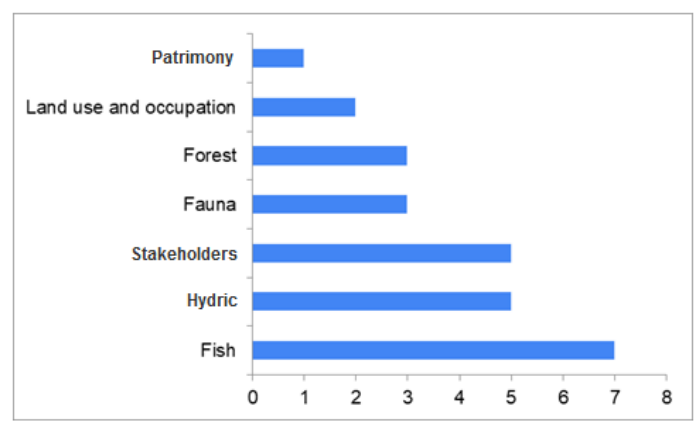

Figure 2. Overview of the subjects identified in the survey data, 2019

As shown in Figure 2, we highlight the studies concerned with the topic dealing with fish and the impact of hydroelectric enterprises in relation to them, object of study of the respective authors (Bhatt, Tiwari, \& Pandit, 2017; Birnie-Gauvin, Larsen, Nielsen, \& Aarestrup, 2017; Cebalho et al., 2017; Lima, Reynalte-Tataje, \& Zaniboni-Filho, 2017; Pittock, Dumaresq, \& Orr, 2017; Quinn, Bond, Brenkman, Paradis, \& Peters, 2017; Yang, Tang, Tao, \& Zhao, 2017).

The data also allowed the identification and classification of the countries that are studied the most (research locus) in the literature regarding the production of renewable energy (hydroelectric). To enable a better understanding, this information was synthesized and organized in Table 1: 
Table 1. Place of study and their respective subjects

\begin{tabular}{|c|c|c|c|}
\hline Country & $\mathbf{N}^{\mathbf{o}}$. & Research locus & Subject \\
\hline \multirow{9}{*}{ Brazil } & \multirow{9}{*}{9} & São Paulo & $\begin{array}{l}\text { Land use and } \\
\text { occupation }\end{array}$ \\
\hline & & Brazilian Amazon & Fauna \\
\hline & & Paraíba do Sul River Basin & Water \\
\hline & & Cabixi I (C1) and Cabixi II (C2) reservoirs & Fish \\
\hline & & Brazilian Amazon & Fauna \\
\hline & & Amazon & Fauna \\
\hline & & Santa Catarina State (Brazil) & Forests \\
\hline & & Region of the Upper Uruguay River & Fish \\
\hline & & Brazilian Amazon & Forests \\
\hline South Africa & 1 & South Africa & Stakeholders \\
\hline Cambodia/Laos/Thailand/Vietinã & 1 & Mekong River & Fish \\
\hline \multirow{2}{*}{ Canada } & \multirow{2}{*}{2} & British Columbia & Stakeholders \\
\hline & & New Brunswick & Patrimony \\
\hline \multirow{2}{*}{ China } & \multirow{2}{*}{2} & Majiang County, Texas & Forests \\
\hline & & Yangtze Basin River & Fish \\
\hline Denmark & 1 & Jutland & Fish \\
\hline \multirow{2}{*}{ Ecuador } & \multirow{2}{*}{2} & Ecuador & Hydric \\
\hline & & In 10 hydroelectric stations & Hydric \\
\hline Usa & 1 & Washington & Fish \\
\hline \multirow{2}{*}{ India } & \multirow{2}{*}{2} & India & Stakeholders \\
\hline & & Himalayas & Fish \\
\hline Mexico & 1 & Sierra Madre Oriental & Hydric \\
\hline Sweden / Norway & 1 & Sweden / Norway & Stakeholders \\
\hline Switzerland & 1 & Walenstadt & Stakeholders \\
\hline Thailand / Myanmar & 1 & Nu Rivers / Salween / Thanlwin & Hydric \\
\hline Viet Nam & 1 & Thua Hue Thien & $\begin{array}{l}\text { Land use and } \\
\text { occupation }\end{array}$ \\
\hline
\end{tabular}

Source: Prepared according to the survey data collection, 2019.

As shown in Table 1, there is a predominance of studies in the Amazon region, more specifically in Brazil, which presented a total higher than $1 / 3$ of the studies reviewed. These data corroborate to previous studies that indicate a potential interest for dam developments in the Amazon basin (Zarfl, Lumsdon, Berlekamp, Tydecks, \& Tockner, 2015). Lees et al. (2016) mapped the existence of 191 dams in the Amazon basin and the construction of 246 more hydroelectric projects.

After data analysis, it was verified that governance in hydroelectric projects is inserted in the paradox of the relationship between society and the environment. Thus, on one hand, there is society that increasingly demands the generation of electricity and has increased its power to participate in decisions when developing hydroelectric projects, however, society itself still suffers from the social impacts of hydroelectric power generation. 
On the other hand, there is a natural environment that suffers several impacts, even though hydroelectric plants are considered an alternative for the generation of clean energy. Among the main impacts suffered by the environment, we can highlight the fragmentation of habitats and the direct consequences for the survival of several species of fish. In this understanding, Figure 3 demonstrates the topics that can be considered indispensable for analysis by governance in hydroelectric projects.

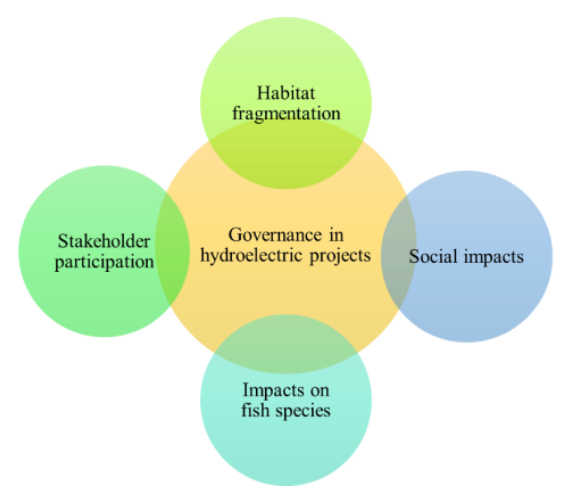

Figure 3. Essential topics to governance in hydroelectric projects, elaborated from the survey data collection, 2019

The analysis and understanding of these topics can be considered indispensable for a good governance of hydroelectric projects. Also based on the data shown in Figure 3, it was verified that these topics can be grouped into three main categories: energy policies; water resources and fish; and biodiversity and ecosystem. In the following section, these categories will be addressed, enabling a better understanding of how these issues have presented themselves in the context of governance in hydroelectric projects.

\section{Discussion}

Regarding hydroelectric power, recent literature has expressed concern about climate change and the growing demands for renewable energy, which consequently lead to interest in the development of hydroelectric plants, as they are considered a renewable source of energy and low carbon emissions that contributes to climate change mitigation, while attracting attention to the environmental and socioeconomic values associated with these enterprises (Karambelkar, 2017; Lindström \& Ruud, 2017; Silber-Coats, 2017).

In this direction, governments of many countries committed internationally to the goal of reducing greenhouse gas emissions and gradually eliminating non-renewable energy sources, have begun to review their energy policies to support a transition to renewable energy sources (Díaz, Adler, \& Patt, 2017). In this perspective, the development of hydroelectric plants can bring many benefits, especially small hydroelectric plants (SHP), which can create employment, improve quality of life, maintenance of social and economic stability, generation of socioeconomic benefits in rural communities, in addition to provide energy supply in remote areas to the existing communities nearby where the projects are executed (Nguyen, Pham, \& de Bruyn, 2017; Silber-Coats, 2017).

Despite these possible benefits, there have been many discussions about the negative impacts of hydroelectric projects, especially in relation to the displacement of communities (riverside and indigenous), habitat loss, and even questions about being really "green" energy sources (Fearnside \& Pueyo, 2012). Thus, these debates involve environmental and social issues that imply the opportunities for the implementation of hydroelectric energy regardless the size of the projects, the type of project and the local conditions of each project.

In this context, based on the review, it was possible to categorize three important thematic groups for the discussion: implications of governance in energy policies; implications of hydroelectric plants on water and fish resources; and implications of hydroelectric plants on biodiversity and ecosystem.

Lindström and Ruud (2017) conceptualize hydroelectric governance as a term that includes different processes of management of hydroelectric resources in relation to: structures of regulations, actions, standards and specific accountability schemes, and various stakeholders.

According to these authors, the current hydroelectric governance model is a consequence of past periods, which were marked by uncontrolled exploration and systems designed to allow the development of hydroelectric plants with little 
regard to the consequences. Thus, it is necessary to understand the political models of the past and regulatory approaches to develop hydroelectric governance systems that are more sustainable and appropriate to future social and environmental needs, especially policies based on the win-win relationship, while maintaining hydroelectric generation in regions where there are no viable options, while minimizing environmental impacts at the local level through new operational projects (Lindström \& Ruud, 2017).

However, depending on the way governments propose energy policies there may be divergences between the government levels and possible conflicts between stakeholders generating public resistance to these policies (Díaz et al., 2017). An event in this sense occurred in British Columbia (BC), Canada, where the government ignored opinions and, contradicting stakeholders, led to the approval of the Site C Hydroelectric Power Plant and the Pacific Northwest Liquefied Natural Gas terminal. This fact consequently led to the discrediting of government consultations for the development of environmental policies (Gerwing \& Cox, 2017).

As for public acceptance, trust and regulatory context are essential variables for measurement, and it is important to understand how they relate to each other and to proceed risk analysis of a negative perception for the implementation of transition projects to renewable energy (Díaz et al., 2017).

In the view of these authors, three perspectives reflect divergences in energy policy at different levels of government: a) promotion for local development and energy production; b) promoting a 'green' environmental agenda at national level; and c) regional government training to implement energy policies. Although these perspectives raise questions about which energy policies should be prioritized, there is consensus from stakeholders on the importance of an inclusive and democratic decision-making process (Díaz et al., 2017).

On the other hand, in some places in the world such as the Indian state of Uttarakhand, laws and policies on electricity, land, environment and water prioritize hydroelectric power generation over other uses of water. In this way, federal and state governments effect regulatory acts that tilt the allocation and distribution of resources and wealth in favor of the development of hydroelectric dams increasingly dominated by the private sector, generating benefits only for developers and the government, while local communities and the environment become virtually non-existent (Karambelkar, 2017).

Given this governmental positioning, a creative solution to promote the balance between the parties is the establishment of formal agreements between localities close to small-scale hydroelectric projects and energy developers for the release of water for irrigation during the planting season, so disputes between water needs for local use and energy development can be minimized without formal regulation (Karambelkar, 2017).

Also, as a possibility to minimize the conflicts between the parties involved in hydroelectric projects, especially in places where there is a complex institutional architecture, there are projects of Small Hydroelectric Power Plants (SHP's), that generate less environmental impact, require simplified authorization processes for the use of water, which consequently allows greater savings of time and costs, benefiting the municipality and the communities served.

Among the SHP's that are contemplated in the literature, we highlight the type implemented in rural areas of South Africa, known as "water wire"- a scheme that generates electricity by the immediate use of the entrance, diverting part or all the river flow through a turbine. Usually, this type of hydroelectric does not have storage capacity, and does not consume water, as the water diverted at the entrance is released back to the river after passing through the turbines (Scharfetter \& van Dijk, 2017).

In Mexico, at Sierra Madre Oriental, Silber-Coats (2017) studied hydroelectric conflicts in Bobos-Nautla from a narrative perspective, classified in three parts: a) the arguments of hydroelectric energy advocates, for which the narrative is the claim that small hydroelectric dams contribute to development being part of a modernization process, generating stability and economic growth for rural communities; b) the counter-narrative of the adversaries, that argues that small hydroelectric projects are a scheme to "steal water", putting privatization as the root of the problem; and that the development of hydroelectric energy is sowing social discord, and c) the points of ambiguity and contradiction, which suggest lack of discursive closure due to the impossibility of including all actors in this conflict in only these two opposing fields.

Another contribution of the author mentioned above is in the historical account of the evolution of hydroelectric governance in Mexico, portraying long-standing conflicts involving the use of water for hydroelectric generation and the various institutional changes that have occurred, ranging from subtle political changes to comprehensive constitutional reforms, reshaping hydroelectric governance in a significant way, with a general trend of transition 
from a centrally planned energy system to a competitive market structure, with the State acting as a facilitator of private investment (Silber-Coats, 2017).

Governance in hydroelectric projects can be understood as an explicit or implicit contractual structure within a transaction occurs. This process should be supported by hierarchical systems of control and incentive to avoid the disastrous consequences that the current standard of development of hydroelectric power presupposes, thus, government agencies should keep in mind broader considerations about sustainability.

In the studies, a relevant concern was raised regarding the impacts of hydroelectric projects on water resources and fish species. These impacts were evidenced in the study by Bhatt, Tiwari and Pandit (2017) who estimated - based on the construction projects of new hydroelectric plants in India - a rate of river diversions around 52 to $88 \%$, and consequently the occurrence of semi-lake river ecosystems in different rivers.

Another relevant aspect that was highlighted by these authors is that the type of hydroelectric plant to be built, mainly cascading, directly impacts the migratory flow of fish (downstream/upstream) hindering the reproduction process of the species. Most hydroelectric projects aim, as an alternative to minimize the environmental impact, the creation of fish in hatcheries and later the introduction of these species in the reservoirs. However, this activity offers risks with the loss of genetic integrity and the possibility of contamination of natural fish populations with hatchery genetic material (Bhatt et al., 2017).

Corroborating the argument that hydroelectric "cascade" causes adverse effects for the migration and reproduction of fish species, more specifically the species (potamodromes) that depend on migration in various parts of the rivers, Yang et al. (2017) highlighted the need to respect a minimum distance of $60 \mathrm{KM}$ between one dam and another, so that it is possible to maintain a riverside habitat that allows fish reproduction.

Also relevant to the importance of fish migration, the revised literature found cases in which the diversity of fish populations was reestablished after the removal of hydroelectric dams, such as the case of the removal of a dam in Denmark and two others in the United States: in the first case, researchers found that after 30 years of the removal of the Vilholt dam, there was an increase in the density of young fish both downstream and upstream of where the dam was located (Birnie-Gauvin et al., 2017). In the United States, the removal of two dams on the Elwha River allowed diadromas species to gain access to the sea again and consequently favored the rescue of the phenomenon of anadromy, that is, it allowed species such as salmon living in the sea to have access to river waters to reproduce (Quinn et al., 2017).

Another concern related to the migratory flow of fish, which has demanded studies in this area, refers to the chemical and genetic changes caused in fish from hydroelectric dams. Cebalho, et al. (2017) compared mercury concentration rates in fish from two Small Hydroelectric Plants (SHP's) with downstream fish from these reservoirs and found an increase in the mercury $(\mathrm{Hg})$ index in fish from the reservoirs. Although this increase in mercury $(\mathrm{Hg})$ is observed, the World Health Organization -WHO still considers it acceptable for consumption? According to the authors of the study, the causes for this are the alteration of the limnological conditions of water through anthropogenic actions of building dams.

As for the issue of water quality, Ling et al. (2017) found that eutrophic reservoirs result from multiple factors, among them stand out: high concentration of nutrients mainly in rainy periods, where organic compounds flow into rivers, given the proximity to areas of agricultural activities, livestock, sewage, and soil erosion. Due to this nutrient flow to the reservoirs, there is a greater proliferation of algae and a decrease in water quality (Ling et al., 2017).

Some of the implications of hydroelectric enterprises on fish species and the use of water resources were presented, more specifically the changes caused in water quality. However, these implications are not restricted to these studies, on the contrary, the level of impacts over the construction of hydroelectric dams gains a complex dimension by analyzing the ecosystem and biodiversity in general.

Reports on environmental impacts on flora, fauna, soil, and landscape were found in the literature, compromising the conservation of biodiversity and ecosystem. Most studies found in this literary review relate the negative effects which will be addressed below - as consequences of the "edge effects" caused by fragmentation and alteration of natural habitats due to floods caused by hydroelectric dams (Palmeirim, Vieira, \& Peres, 2017; Storck-Tonon \& Peres, 2017; Urruth, Souza, \& Oliveira, 2017).

An example of a change in the flora on the shores of areas flooded by hydroelectric dams was demonstrated by Jones et al. (2017) when verifying the predominance of woody lianas over other tree species in degraded areas. Such change in vegetation, in addition to harming the diversity of other species, still results in indirect consequences, such 
as: the loss of biomass and the reduction of carbon retention by means of tree species (Jones, Peres, Benchimol, Bunnefeld, \& Dent, 2017).

Based on this correlation of vegetation change, it is still possible to assume other environmental impacts, such as temperature rise, climate change and changes in precipitation rates as well as impacts on terrestrial fauna.

In this sense, Palmeirim, Vieira and Peres conducted a study in the Brazilian Amazon, more specifically at the Balbina Hydroelectric Power Plant, where they observed lizards that inhabited islands with approximately 100 ha that formed around the plant after 28 years of its construction. In this study, the authors highlighted the dominance of heliophilous species and point out that this fact results from higher temperatures during the day due to numerous gaps in the forest and direct exposure to sunlight (Palmeirim et al., 2017).

In addition to these negative effects, the literature also contemplates concerns about pollinating animals such as bee species, revealing that the distance between forests and island regions due to floods caused by hydroelectric plants is a threat to plant pollination function (Storck-Tonon \& Peres, 2017).

Another animal identified in the literature and considered as an important indicator of ecosystem health was the bat. One study analyzed bat species in the previous period and after the construction of a hydroelectric plant, and the results showed that the diversity of species is conditioned to the variation of landscape, vegetation, and topography (Bobrowiec \& Tavares, 2017).

From these studies presented, it is perceived that the edge effects resulting from hydroelectric projects results in serious environmental impacts, mainly related to biodiversity and habitat maintenance, thus, such effects have caused the dominance of few species and threatens the diversity of the other species, whether fauna or flora.

\section{Conclusion}

The importance of governance in hydroelectric projects was discussed and expanded in this research, especially regarding the manifestation of governance and the impacts on natural resources resulting from these enterprises. In this sense, this research aimed to provide an overview on the subject, using a systematic review of the literature on governance of hydroelectric enterprises and a qualitative analysis, which allowed the categorization of three main categories: governance in energy policies; water resources and fish; biodiversity and ecosystem.

In relation to governance in energy policies, the studies point the importance of strategically engaging with a variety of stakeholders, with the intention of creating positive and respectful relationships aimed at minimizing existing conflicts. As presented by the authors Díaz, Adler and Patt (2017), although there is disagreement involving issues on energy policies, stakeholders broadly agree on the importance of an inclusive and democratic decision-making process, so that solid and reliable governance is encouraged.

Regarding governance for water resource management, this is a broad topic and involves a range of problems, demonstrating that effective and coordinated water governance systems are needed, otherwise, purely technical solutions will fail.

Associated with the governance of water resources and the impacts generated by hydroelectric plants, it is pertinent to highlight the concern with aquatic species. The survival of fish diversity and its distribution needs to be ensured through adequate environmental flows, under an ecologically sustainable and integrated water management program (Bhatt et al., 2017).

In relation to biodiversity, it is pertinent to present the considerations of Pandit and Grumbine (2012) who argue that the construction of dams results in adverse effects on the preservation of species. Forest loss and fragmentation significantly affect species diversity, cause changes in land cover and use, and submersion procedures result in the direct elimination of species, so activities related to the construction of dams end up being harmful to the survival of species (Pandit \& Grumbine, 2012).

Although there is a strong opposition to the implementation of hydroelectric energy projects, especially projects involving the construction of large dammed reservoirs, it cannot be denied their relevance to the economic development process, especially for developing countries that need to meet energy demands and at the same time contribute to the reduction of greenhouse gas emissions - GHG.

In this sense, the literature has emphasized the importance of environmental and social aspects being considered in the planning, construction, and operationalization of hydroelectric plants, given their important role in the world's energy supply. Another issue that needs to be highlighted is that governance requirements are complex and should be applied vertically considering a top-down approach to structure the strategy and bottom-up to get the right incentives and controls (Grigg, 2011). 
Finally, this research provided relevant information on governance in hydroelectric plants and the impacts on natural resources resulting from the construction of dams. With this it is expected to have contributed academically to broaden the discussion on this subject and even foster future research, in addition, the information presented here can serve to guide all those involved in hydroelectric projects.

Due to the complexity and scope of this topic, there is great potential for further research. Empirical studies that include alternative perspectives or paradigms of governance are advocated, especially in developing countries, so that this line of research can contribute to the development of intelligent governance arrangements that are capable of dealing with conflicts arising from hydroelectric projects and the use of natural resources in more effective ways.

It is also suggested that future research explores corporate governance in hydroelectric projects and stakeholders, because few empirical research has been found on this subject; role of corporate governance in social and environmental performance, including under corporate social responsibility and environmental performance; studies on the socioeconomic and environmental impacts of hydroelectric projects and how technologies can contribute to minimize the "edge effects" caused by fragmentation and alteration of natural habitats due to floods caused by hydroelectric plants; studies on the impact on poverty reduction of local and indigenous communities, due to few studies on the direct relationship between better corporate governance and greater poverty alleviation and inequality reduction.

Among the limitations of this research, we point out the fact that only one bibliographic database (Scopus) was used and the selection of articles of free access in the English language. Thus, it is possible that this review did not include all the peculiarities related to governance and impacts on the use of natural resources in hydroelectric projects.

\section{Declaration of Competition interest}

The authors declare that there is no conflict of interest.

\section{Acknowledgements}

We thank the Coordination for the Improvement of Higher Education Personnel (CAPES) and the professors of the Graduation Program in Administration of the Federal University of Rondônia (PPGA/UNIR) for the support provided in the realization of this article.

In memory, we thank our friend Sidney dos Reis for all his contribution to this work.

\section{References}

Baas, J., Schotten, M., Plume, A., Côté, G., \& Karimi, R. (2020). Scopus as a curated, high-quality bibliometric data source for academic research in quantitative science studies. Quantitative Science Studies, 1(1), 377-386. https://doi.org/10.1162/qss_a_00019

Bardin, L. (1977). Content Analysis.pdf. In Content Analysis.

Bhatt, J. P., Tiwari, S., \& Pandit, M. K. (2017). Environmental impact assessment of river valley projects in upper Teesta basin of Eastern Himalaya with special reference to fish conservation: a review. Impact Assessment and Project Appraisal, 35(4), 340-350. https://doi.org/10.1080/14615517.2017.1354642

Birnie-Gauvin, K., Larsen, M. H., Nielsen, J., \& Aarestrup, K. (2017). 30 years of dramatic reveal data increase in abundance of brown trout following the removal of a small hydrodam. Journal of Environmental Management, 204, 467-471. https://doi.org/10.1016/j.jenvman.2017.09.022

Bobrowiec, P. E. D., \& Tavares, V. D. C. (2017). Establishing baseline biodiversity data prior to hydroelectric dam construction to monitoring impacts to bats in the Brazilian Amazon. PLoS ONE, 12(9). https://doi.org/10.1371/journal.pone.0183036

Campos, V. N. D. O., \& Fracalanza, A. P. (2010). Water governance in Brazil: Conflicts over water appropriation and the search for integration as consensus. Environment and Society. https://doi.org/10.1590/S1414-753X2010000200010

Cebalho, E. C., Díez, S., Dos Santos Filho, M., Muniz, C. C., Lázaro, W., Malm, O., \& Ignácio, A. R. A. (2017). Effects of small hydropower plants on mercury concentrations in fish. Environmental Science and Pollution Research, 24(28), 22709-22716. https://doi.org/10.1007/s11356-017-9747-1

Chandy, T., Keenan, R. J., Petheram, R. J., \& Shepherd, P. (2012). Impacts of Hydropower Development on Rural Livelihood Sustainability in Sikkim, India: Community Perceptions. Mountain Research and Development. https://doi.org/10.1659/mrd-journal-d-11-00103.1 
Cooper, R. N., \& Khagram, S. (2005). Dams and development: transnational struggles for water and power. Foreign Affairs, 84(1), 181. https://doi.org/10.2307/20034226

Díaz, P., Adler, C., \& Patt, A. (2017). Do stakeholders' perspectives on renewable energy infrastructure pose a risk to energy policy implementation? A case of a hydropower plant in Switzerland. Energy Policy, 108, 21-28. https://doi.org/10.1016/j.enpol.2017.05.033

Diduck, A. P., Pratap, D., Sinclair, A. J., \& Deane, S. (2013). Perceptions of impacts, public participation, and learning in the planning, assessment and mitigation of two hydroelectric projects in Uttarakhand, India. Land Use Policy. https://doi.org/10.1016/j.landusepol.2013.01.001

Fearnside, P. M., \& Pueyo, S. (2012). Greenhouse-gas emissions from tropical dams. Nature Climate Change, 2(6), 382-384. https://doi.org/10.1038/nclimate1540

Galvão, T. F., Pansani, T. de S. A., \& Harrad, D. (2015). Main items to report Systematic reviews and Meta-analyses: The PRISMA recommendation. Epidemiology and Health Services, 24(2), 335-342. https://doi.org/10.5123/S1679-49742015000200017

Gerwing, T. G., \& Cox, K. (2017). Erosion of trust in government consultation will impede the creation of environmental policy. Marine Policy, 83, 126-127. https://doi.org/10.1016/j.marpol.2017.06.005

Ghosh, S. (2011). Hydrological changes and their impact on fluvial environment of the lower damodar basin over a period of fifty years of damming The Mighty Damodar River in Eastern India. Procedia - Social and Behavioral Sciences, 19, 511-519. https://doi.org/10.1016/j.sbspro.2011.05.163

Gough, D., Oliver, S., \& Thomas, J. (2017). An introduction to systematic reviews. Sage.

Grigg, N. S. (2011). Water governance: from ideals to effective strategies. Water International, 36(7), 799-811. https://doi.org/10.1080/02508060.2011.617671

Guixiang, C. (2006). Solutions to ecological and environmental issues in rural hydropower development. China Water Resources, 20. Retrieved from http://en.cnki.com.cn/Article_en/CJFDTotal-SLZG200620009.htm

Jones, I. L., Peres, C. A., Benchimol, M., Bunnefeld, L., \& Dent, D. H. (2017). Woody lianas increase in dominance and maintain compositional integrity across an Amazonian dam-induced fragmented landscape. PLoS ONE, 12(10). https://doi.org/10.1371/journal.pone.0185527

Karambelkar, S. (2017). Hydropower development in India: The legal-economic design to fuel growth?. Natural Resources Journal, 57(2), 361-394.

Kaygusuz, K. (2002). Sustainable Development of Hydroelectric Power. Energy Sources, 24(9), 803-815. https://doi.org/10.1080/00908310290086725

Klimpt, J.-É., Rivero, C., Puranen, H., \& Koch, F. (2002). Recommendations for sustainable hydroelectric development. Energy Policy, 30(14), 1305-1312.

Lees, A. C., Peres, C. A., Fearnside, P. M., Schneider, M., \& Zuanon, J. A. S. (2016). Hydropower and the future of Amazonian biodiversity. Biodiversity and Conservation, 25(3), 451-466. https://doi.org/10.1007/s10531-016-1072-3

Lima, F. T. D., Reynalte-Tataje, D. A., \& Zaniboni-Filho, E. (2017). Effects of reservoirs water level variations on fish recruitment. Neotropical Ichthyology, 15(3). https://doi.org/10.1590/1982-0224-20160084

Lindström, A., \& Ruud, A. (2017). Who's hydropower? From conflictual management into an era of reconciling environmental concerns; A retake of hydropower governance towards win-win solutions?. Sustainability, 9(7). https://doi.org/10.3390/su9071262

Ling, T.-Y., Gerunsin, N., So, C.-L., Nyanti, L., Yes, S.-F., \& Grinang, J. (2017). Seasonal changes and spatial variation in water quality of a large young tropical reservoir and its downstream river. Journal of Chemistry, 2017. https://doi.org/10.1155/2017/8153246

Nguyen, H. T., Pham, T. H., \& De Bruyn, L. L. (2017). Impact of hydroelectric dam development and resettlement on the natural and social capital of rural livelihoods in bo hon village in central Vietnam. Sustainability, 9(8). https://doi.org/10.3390/su9081422

Palmeirim, A. F., Vieira, M. V., \& Peres, C. A. (2017). Non-random lizard extinctions in land-bridge Amazonian forest islands after 28 years of isolation. Biological Conservation, 214, 55-65. https://doi.org/10.1016/j.biocon.2017.08.002 
Pandit, M. K., \& Grumbine, R. E. (2012). Potential effects of ongoing and proposed hydropower development on terrestrial biological diversity in the Indian Himalaya. Conservation Biology, 26(6), 1061-1071. https://doi.org/10.1111/j.1523-1739.2012.01918.x

Pittock, J., Dumaresq, D., \& Orr, S. (2017). The Mekong River: trading off hydropower, fish, and food. Regional Environmental Change, 17(8), 2443-2453. https://doi.org/10.1007/s10113-017-1175-8

Quinn, T. P., Bond, M. H., Brenkman, S. J., Paradis, R., \& Peters, R. J. (2017). Re-awakening dormant life history variation: stable isotopes indicate anadromy in bull trout following dam removal on the Elwha River, Washington. Environmental Biology of Fishes, 100(12), 1659-1671. https://doi.org/10.1007/s10641-017-0676-0

Rai, R. K., Bhatta, L. D., Dahal, B., Rai, B. S., \& Wahid, S. M. (2019). Determining community preferences to manage conflicts in small hydropower projects in Nepal. Sustainable Water Resources Management, 5(3), 1103-1114. https://doi.org/10.1007/s40899-018-0285-x

Sadler, B., Verocai, I., \& Vanclay, F. (2000). Environmental and Social Impact Assessment for Large Dams, Thematic Review V. 2 prepared as an input to the World Commission on Dams, Cape Town. Retrieved from http://www.agsci.utas.edu.au/WCDreportEIA\&dams.pdf\%3E

Scharfetter, B., \& Van Dijk, M. (2017). Legislation governing the implementation of small-scale hydropower projects for rural electrification in South Africa. Journal of Energy in Southern Africa, 28(2), 14-28. https://doi.org/10.17159/2413-3051/2017/v28i2a2005

Silber-Coats, N. (2017). Clean energy and water conflicts: Contested narratives of small hydropower in Mexico's Sierra madre oriental. Water Alternatives, 10(2), 578-601.

Storck-Tonon, D., \& Peres, C. A. (2017). Forest patch isolation drives local extinctions of Amazonian orchid bees in a 26 years old archipelago. Biological Conservation, 214, 270-277. https://doi.org/10.1016/j.biocon.2017.07.018

Tayeng, R. (2015). Hydropower Dams and Development: Local Perspectives. Online International Interdisciplinary Research Journal, $\quad V, \quad 335-350 . \quad$ Retrieved from http://www2.ce.metu.edu.tr/ ce571/links/announcement/LowRes_Hydropower_in_Sustainable_Developme

Tranfield, D., Denyer, D., \& Smart, P. (2003). Towards a methodology for developing evidence-informed management knowledge by means of systematic review. British Journal of Management. https://doi.org/10.1111/1467-8551.00375.

Urruth, L. M., Souza, A. F., \& Oliveira, J. M. (2017). Does hydroelectric reservoirs affect the structure of surrounding tree communities? A test of hypotheses in subtropical South America. Revista Brasileira de Botanica, 40(3), 705-715. https://doi.org/10.1007/s40415-017-0376-1

Yang, Z., Tang, H., Tao, J., \& Zhao, N. (2017). The effect of cascaded huge dams on the downstream movement of Coreius guichenoti (Sauvage \&; Dabry de Thiersant, 1874) in the upper Yangtze River. Environmental Biology of Fishes, 100(11), 1507-1516. https://doi.org/10.1007/s10641-017-0661-7

Yoffe, S., Wolf, A. T., \& Giordano, M. (2003). Conflict and cooperation over international freshwater resources: Indicators of basins at risr 1. JAWRA Journal of the American Water Resources Association, 39(5), 1109-1126.

Zarfl, C., Lumsdon, A. E., Berlekamp, J., Tydecks, L., \& Tockner, K. (2015). A global boom in hydropower dam construction. Aquatic Sciences, 77(1), 161-170. https://doi.org/10.1007/s00027-014-0377-0

\section{Copyrights}

Copyright for this article is retained by the author(s), with first publication rights granted to the journal.

This is an open-access article distributed under the terms and conditions of the Creative Commons Attribution license (http://creativecommons.org/licenses/by/4.0/). 